\title{
Transcriptome analysis for the restrained stem development of the wheat mutant $d m s$
}

\author{
Ruishi He ${ }^{1}$ Xinxin $Z_{h u^{1}}$ Qiaoyun Li $^{1}$ Yumei Jiang ${ }^{1}$ Dongyan Yu ${ }^{1}$ \\ Yulong Sun ${ }^{1}$ Xiaolong Liang ${ }^{1}$ Yongjing $\mathrm{Ni}^{1,2}$ Jishan $\mathrm{Niu}^{{ }^{*}}$
} ${ }^{1}$ National Centre of Engineering and Technological Research for Wheat, Henan Agricultural University, Zhengzhou, 450002, China. E-mail:
jsniu@263.net. "Corresponding author.

${ }^{2}$ Shangqiu Academy of Agricultural and Forestry Sciences, Shangqiu, 476000, China.

\begin{abstract}
Wheat (Triticum aestivum L.) stem development significantly affects grain yield. The dwarf plants (D) of wheat mutant dms was less than $30 \mathrm{~cm}$. Here, we were to explore the molecular basis for the restrained stem development of the $d$ warf plants. The results were reached by compare the young spikes and stems transcriptomes of the tall $(T)$ and D plants of mutant dms. We identified 663 genes highly expressed in stem tips. We identified 997 differentially expressed genes (DEGs) in stem tips between T and D, 403 DEGs were significantly related with stem development. Most biological processes in stem tips on dwarf plants were significantly suppressed, such as phytohormone signaling etc. The sequencing analysis results were confirmed by quantitatively analysis the expression profiles of fourteen key DEGs via real-time QRT-PCR. We identified a group genes related to wheat stem development, identified a group DEGs related to the restrained stem development of D plants of dms. The suppressed phytohormone signaling, carbohydrate transport and metabolism were the major causal factors leading to dwarf plants of $D$. Our dataset provides a useful resource for investigating wheat stem development.

Key words: Wheat (Triticum aestivum L.); dms mutant; transcriptome; stem development.
\end{abstract}

Desenvolvimento e análise de transcriptoma de uma haste de trigo mutante dms

RESUMO: O desenvolvimento da haste do trigo (Triticum aestivum L.) afeta significativamente o rendimento dos grãos. A partir disso, empregou-se a base molecular para o desenvolvimento de uma haste de variedade de trigo. Os resultados foram alcançados ao conferir as hastes de um mutante de trigo DMS. Identificou-se 663 genes altamente expressos na haste; 997 genes (DEGs) diferentemente expressos em hastes entre T e D e; 403 DEGs foram significativamente diferentes. A maioria dos processos biológicos de caule tipo não plantas foram significativamente suprimidas, com o fito hormônio de sinalização. Os resultados da análise de sequencia foram confirmados pela expressão quantitativa de perfis de catorze chave DEGs através de qRT-PCR em tempo real. Nota-se um grupo de genes relacionados com a haste de trigo de desenvolvimento. Identificou-se um grupo DEGs relacionados com o desenvolvimento de um tronco D plantas de DMS. O fito hormônio de sinalização, transporte e metabolismo de hidratos de carbono foram os principais fatores suscetíveis das plantas anão de D. Nosso conjunto de dados fornece um recurso útil para investigar o desenvolvimento do caule de trigo. Palavras-chave: trigo (Triticum aestivum L.), DMS Mutante transcriptoma; caule; desenvolvimento.

\section{INTRODUCTION}

Wheat (Triticum aestivum L.) stem development is the premise for wheat harvest yield. Two types of dwarf genes exist in wheat germplasms, dwarf and semi-dwarf genes. Dwarf genes can significantly reduce wheat plant height, but the effect of semi-dwarf genes was relatively little (LIANG et al., 2004).

Gibberellins (GAs) affected plant height (YAMAGUCHI, 2008). Most dwarf or semi-dwarf genes affect plant height by regulation GA pathway (WANG et al., 2015). The biosynthetic pathways of GAs have been studied clearly since they were identified (Peng et al., 1997), but how dwarf or semidwarf genes effect on plant height via GA pathway was not clear. In some cases, GAs effect on wheat plant height was connected with DELLA gain-offunction mutations (WU et al., 2011).

Today, high-throughput sequencing has been known as a routine technology for transcriptome analysis (TAKETO et al., 2016). The global gene expression profile in differentiating stems can help us to investigate the mechanism more clearly. Formerly, we obtained a dwarf $(d m s)$ mutant from cultivar 'Zhoumai 18'. There are three plant height lines D, semi-dwarf (M) and $\mathrm{T}$ in the progeny of $d m s$, and they 
were stable (DUAN et al., 2015). In order to explore the molecular basis of stem development of $d m s$, we performed RNA- sequencing analysis to obtain the DEGs between the T and D plants. DEGs involved in phytohormone signaling, carbohydrate transport and metabolism were found. The present work could help us to understand wheat stem development.

\section{MATERIALS AND METHODS}

\section{Plant materials and growth conditions}

Zhoumai 18, D, M and T plants of $d m s$ mutant were used as plant materials. Among the three typical phenotypes in the progeny of mutant $d m s$, T plants were the same phenotype as Zhoumai 18, M plants were dwarf, only D plants were dwarf, multi-pistil and male sterility. The mutant was kept by sowing seeds from the M plants every year. The plant height followed a segregation ratio of 1:2:1 (T:M:D=1:2:1) (DUAN et al., 2015). The seed were sown in plots of $3.0 \mathrm{~m}$ in length and $2.3 \mathrm{~m}$ in width, the distance between rows was $0.21 \mathrm{~m}, 30$ seeds were planted in each row.

\section{Sample preparation and sequence analysis}

The sample preparation and total RNA extraction of young spikes and stem tips of D and $\mathrm{T}$ were carried out as we reported early (ZHU et al., 2016). Each of the four super bulks contains more than 20 individuals, bulks have no replicates. Trscriptome sequencing and the data analysis were done by using an Illumina HiSeqTM 2000 in BioMarker Company (Beijing, China). Transcriptomes were assembled using software Trinity with parameters of K-mer = 25 , group pairs distance $=500$ (GRABHERR et al., 2011). RPKM was used to calculate gene expression level (MORTAZAVI et al., 2008). DEGs were identified and clustered by software IDEG6 ( $p<$ 0.01 , ratio of RPKM $\geq 2$ ) (ROMUALDI et al., 2003) and Cluster 3.0 (EISEN et al., 1998), respectively. Genes were annotated referring to NR < http://www. ncbi.nlm.nih.gov/>, SwissProt and TrEMBL < $<$ ttp:// www.uniprot.org/>, KEGG <http://www.genome. $\mathrm{jp} / \mathrm{kegg} />$, and GO <http://www.geneontology.org/> databases. The detailed parameters were as described previously (ZHU et al., 2016).

\section{qRT-PCR}

The stem samples of Zhoumai 18, D, M and $\mathrm{T}$ lines were prepared at 11 time points for real time qRT-PCR; the interval of the 11 time points were about three days from March $9^{\text {th }}$ to April $10^{\text {th }}$. Each sample included ten independent stem tips for
RNA extraction. First-strand cDNA was synthesized with $1.5 \mu \mathrm{g}$ total RNA. Primers for qRT-PCR were listed in table 1. All qRT-PCRs were performed as we described early (ZHU et al., 2016). Wheat actin gene was used as internal control for normalization, all the annealing temperature of primers was performed at $60^{\circ} \mathrm{C}$ in the experiment. All experiments were three technical replicates, and the gene expression levels were calculated according to the $2^{-\Delta \Delta C T}$ method (LIVAK AND SCHMITTGEN 2001).

\section{RESULTS}

The expressions of most genes in stem tips were different between $D$ and $T$

Total 128,619 unigenes were de novo assembled, 90,424 unigenes were annotated for biological functions(Zhu etal., 2016). The transcriptome data of the young stem tips on D and T were different, including reads number $(30,561,521 ; 35,002,292)$, base number $(6,172,866,126 ; 7,069,797,729)$ and $d e$ novo assembled unigenes $(72,423 ; 70,413)$.

\section{The genes involved in wheat stem development \\ Compared to young spikes, total 663} genes were obtained highly expressed in stem tips. Functional classification based on GO suggested that the following aspects were more active in stem tips than in their spikes: (1) cellular component: extracellular region, cell junction, membrane etc; (2) molecular function: transporter, electron carrier, antioxidant, nutrient reservoir, translation regulator and metallochaperone activity etc; (3) biological process: response to stimulus, developmental process, establishment of localization, pigmentation and cell killing etc (Figure 1). It showed that most biological processes and major gene expressions were activated in stem tips development.

Gene functional annotation indicated 48 genes of the 663 genes were clearly concerned with stem development. They were homeotic/homobox genes, transcription factors (Gene expression), protein kinases, and carbohydrate metabolism genes, etc. 'Gene expression' section had eighteen unigenes and 'carbohydrate metabolism' had three unigenes that implied they each played an important role in stem development. Some genes were clear involved in stem development, such as cell development (T1-51819), organ morphogenesis (T1-56670), organ growth (T1-59903; T3-17722; T1-56578; T3-10488), auxin mediated signaling pathway, meristem development and response to cytokinin stimulus (T1-67257; T4-32688), cellulase activity (T3-14939), lignin 
Table 1 - The primers used in QRT-PCR.

\begin{tabular}{|c|c|c|c|c|c|}
\hline Unigene ID & Gene name & Forward primer $\left(5^{\prime}-3^{\prime}\right)$ & Backward primer $\left(5^{\prime}-3^{\prime}\right)$ & $\begin{array}{l}\text { Produc } \\
\text { t length } \\
\text { (bp) }\end{array}$ & $\begin{array}{l}\mathrm{Tm} \\
\left({ }^{\circ} \mathrm{C}\right)\end{array}$ \\
\hline $\mathrm{T} 1-54863$ & CSLE6 & GGAGTCGGTCTACAACAATCCTAA & CATAATACAGCGTAGCGAGTGAGT & 230 & 58.5 \\
\hline T3-50471 & CKX9 & TGAGGACAAGGGTAGTGACGC & AACAAAGCAAGTATTGGGGTGA & 186 & 59.5 \\
\hline T3-9216 & $\begin{array}{c}\text { LOC_Os10g } \\
19280\end{array}$ & TCCGCAGTCCTCCTGTAGTTT & TGCAAGATGGCTGAGGGTAGT & 232 & 59.3 \\
\hline $\mathrm{T} 4-57859$ & ARF25 & CCTTTCCAATGTATCCAACTGC & ACGACTGAGCCCCTCTATCC & 162 & 58.6 \\
\hline T1-69403 & At4g08850 & CTTATCAGCATCTTTGGAGGGTA & ATCGGTGCGAAGCAGTCAT & 123 & 58.4 \\
\hline $\mathrm{T} 1-66145$ & HAK1 & GTGTCACAGGCACAGAAGGC & GCGATGATGGCAGCAAGA & 229 & 58.3 \\
\hline $\mathrm{T} 2-38565$ & SWEET11 & ТСТСССТСССТССТТТССТС & AGCCATTGCGACCACGA & 89 & 58.6 \\
\hline T3-62471 & PSAH & CAAGTACGGGGAGAAGAGCG & CGGCGAAGGTGTTGAAGAA & 134 & 59.6 \\
\hline T3-5609 & $\begin{array}{c}\text { Os06g01077 } \\
00\end{array}$ & ACCCCAACGCAACCATCA & AACTTGTAGTCCTCGTGCTCCTC & 103 & 59.7 \\
\hline $\mathrm{T} 2-50808$ & PFP-BETA1 & CTTTGTGAGGCTTATGGGTCG & TCTGTGACATTCTTGAGTGTTTCC & 129 & 59.0 \\
\hline T4-58749 & CSFL8 & CTACTTGGATGGCTGATGGGT & GGGTGGTGTCCTTTCCTGTG & 82 & 59.4 \\
\hline $\mathrm{T} 1-64213$ & ACT-2 & GACAATGTTTTGCCCTGACCT & CATCGAGCGCCATGAAGAG & 182 & 59.4 \\
\hline $\mathrm{T} 1-61048$ & WAKL1 & AACGGTGCTTGAGGCTGTG & CTTGGTTGCATCTGTTCTTCG & 133 & 58.7 \\
\hline T3-34007 & SAIN2 & TCACTCGGCGGTGGATTT & CCTTCGACCTGAGGATACGG & 91 & 59.2 \\
\hline gi:48927617 & Actin & GGGACCTCACGGATAATCTAATG & CACCTGAACCTTTCTGAACCAA & 223 & 59.5 \\
\hline
\end{tabular}

${ }^{*} \mathrm{~T} 1$ : gene nubmer of stem tips on D, T2: gene nubmer of spikes on D, T3: gene nubmer of stem tips on T, T4: gene number of spikes on T. ${ }^{* *}$ T1-54863: Cellulose synthase-like protein E6; T3-50471: Cytokinin dehydrogenase 9; T3-9216: Retrovirus-related Pol polyprotein from transposon TNT 1-94; T4-57859: Auxin response factor 25; T1-69403: Probable LRR receptor-like serine -protein kinase At4g08850; T166145: Potassium transporter 1; T2-38565: Bidirectional sugar transporter SWEET11; T3-62471: Photosystem I reaction center subunit VI, chloroplastic; T3-5609: Ferredoxin-NADP reductase, leaf isozyme, chloroplastic; T2-50808: Pyrophosphate-fructose 6-phosphate 1phosphotransferase subunit beta 1; T4-58749: Probable mixed-linked glucan synthase 8; T1-64213: Agmatine coumaroyl transferase-2; T161048: Wall-associated receptor kinase-like 1; T3-34007: Salt-induced protein.

biosynthetic process (T1-66751; T4-38347), these were typical biological processes of stem development.

\section{The DEGs between stem tips of $T$ and $D$}

Compared the transcrioptomes of stem tips of T and D, total 997 DEGs were obtained. Among the 997 DEGs, 644 genes were activated and 353 genes were suppressed in stem tips of D regarding T as control. Among the 997 DEGs, 403 genes were significantly related with stem development based on functional annotation. The 403 significative DEGs were divided into several groups (Table 2).

Regarding stem tips of $\mathrm{T}$ as control, 24 pathways were activated, 34 pathways were suppressed, 27 pathways had activated and suppressed DEGs in stem tips of D by KEEG pathway enrichment analysis. Manual analysis was also carried out. The results suggested that most metabolism pathways were different between $\mathrm{T}$ and $\mathrm{D}$, especially were plant hormone signal transduction, photosynthesis - antenna proteins, glycolysis/gluconeogenesis, etc (Table 2). Most biological processes of stem tips on dwarf plants were significantly suppressed, such as transcription, carbohydrate transport and metabolism, energy production and conversion, as well as cellular component (Table 2). In summary, carbohydrate metabolism and general metabolism lower were the major causes for dwarfing of the D plants.

\section{Expression profiles of fourteen genes in stem tips}

To demonstrate the reliability of the sequencing results, we selected fourteen of the significant DEGs to do qRT-PCR. The linear regression analysis demonstrated that the results of super bulk RNA sequencing were reliable (Figure 2).

Expression profile analysis also showed the important roles of the 14 genes during wheat stem development. A LRR protein kinase At4g08850 gene (T1-69403, Figure 2a) and a wall-associated receptor kinase-like gene (T1-61048, Figure 2b) were significantly suppressed in $\mathrm{D}$, however they were highly expressed in T, M and 'Zhoumai 18', that suggested their transcripts were abundant and they played basic roles in stem development. Mutation significantly restrained the expression of a potassium transporter gene (T1-66145, Figure 2c); a cellulose synthase-like 


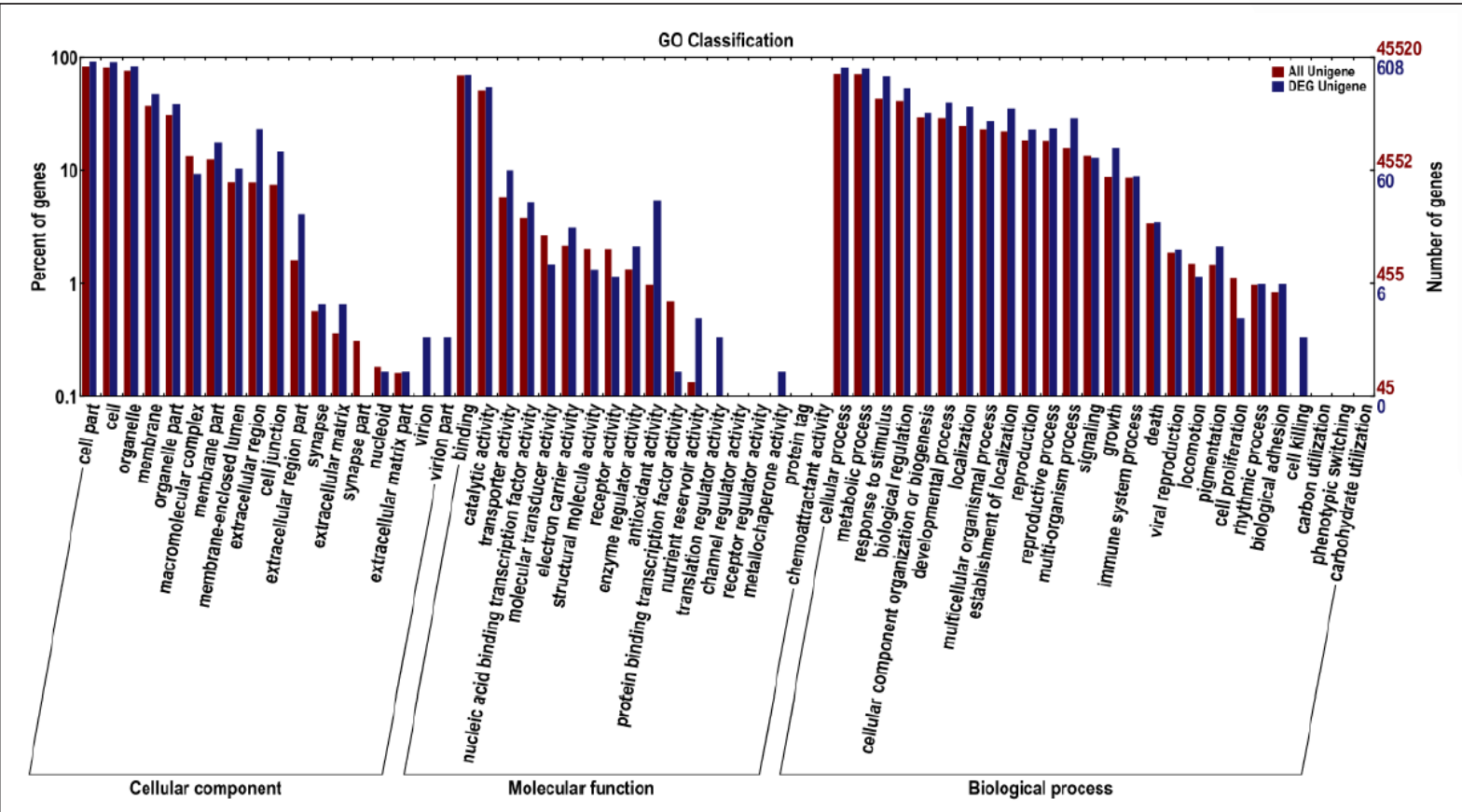

Figure 1 - Functional classification of the DEGs that highly expressed in stems of both D and T; Genes were divided into "cellular component", "molecular function" and "biological process" based on GO database.

protein E6 gene (T1-54863, Figure 2d); and a saltinduced protein gene (T3-34007, Figure 2e). Mutation significantly activated the expressions of a retrovirusrelated Pol polyprotein from transposon TNT gene (T3-9216, Figure 2f); a bidirectional sugar transporter gene (T2-48565, Figure 2g); and a probable mixedlinked glucan synthase gene (T4-58749, Figure 2h). The eight genes almost only expressed or completely suppressed in D. The results suggested that they played important roles in wheat stem development.

Table 2 - Functional classification of significative DEGs in stem tips, stem tips of $\mathrm{T}$ as control

\begin{tabular}{lccc}
\hline Biological processes & Total number of genes & up-regulated genes & down-regulated genes \\
\hline Cellular component & 60 & 27 & 33 \\
Energy production and conversion & 34 & 15 & 19 \\
Replication, recombination and repair & 8 & 4 & 4 \\
Transcription & 53 & 22 & 31 \\
Translation, ribosomal structure and biogenesis & 11 & 2 & 9 \\
Posttranslational modification, protein turnover & 6 & 2 & 4 \\
Amino acid transport and metabolism & 26 & 18 & 8 \\
Signal transduction mechanisms & 12 & 4 & 8 \\
Response to out stimulus & 20 & 10 & 10 \\
Cell cycle control, cell division, chromosome partitioning & 6 & 2 & 4 \\
Photosynthesis & 30 & 11 & 19 \\
Carbohydrate transport and metabolism & 47 & 22 & 25 \\
Plastid & 6 & 2 & 4 \\
Lipid transport and metabolism & 19 & 7 & 12 \\
Inorganic ion transport and metabolism & 4 & 3 & 1 \\
\hline General function & 31 & 22 & 22 \\
\hline Unkown & 30 & 8 & 9 \\
\hline
\end{tabular}

Ciência Rural, v.47, n.12, 2017. 


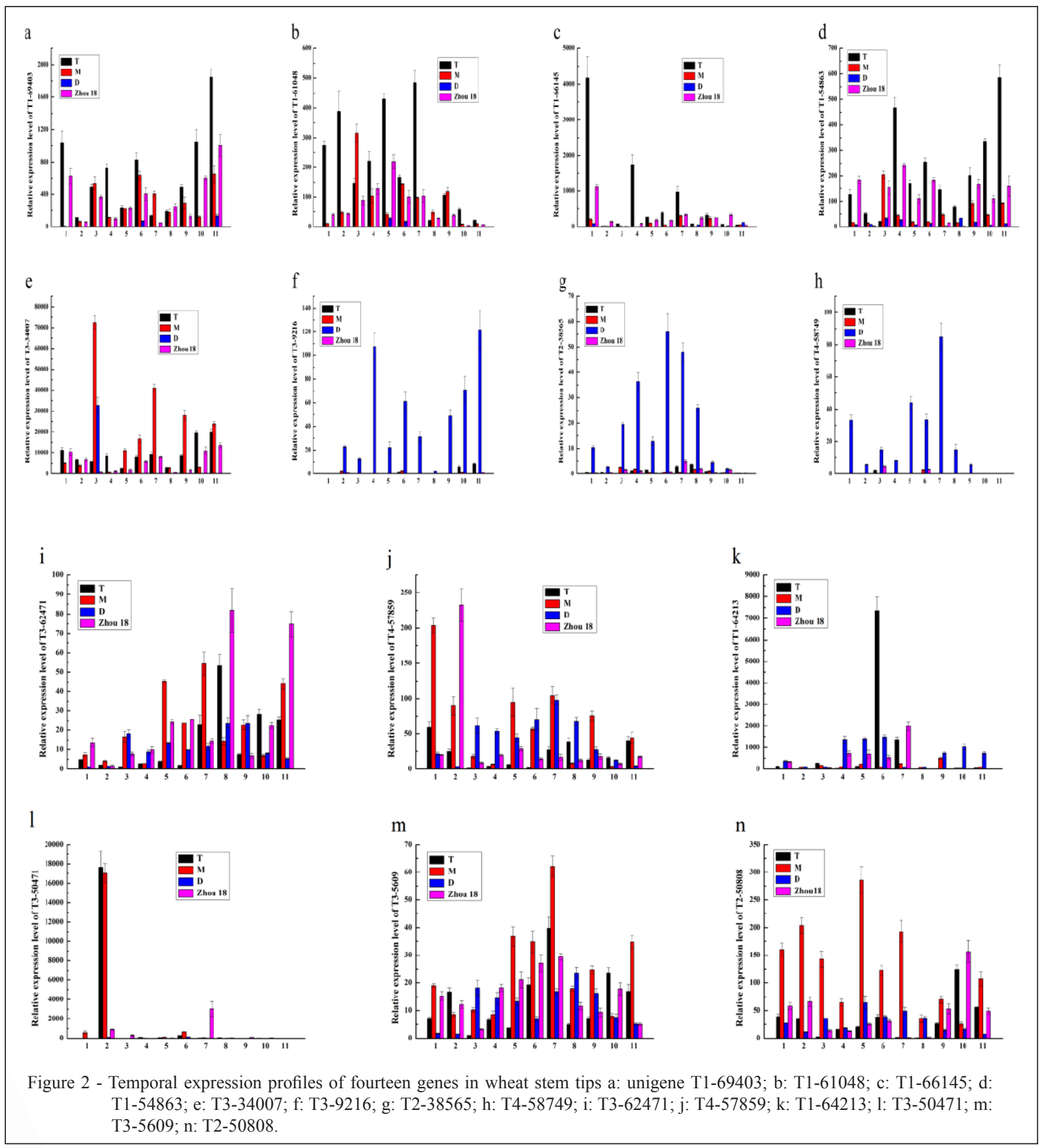

The expression of photosystem I reaction center subunit VI gene was increasing during stem developed in $\mathrm{D}$, its expression level was higher in $\mathrm{T}$ (T3-62471, Figure 2i). An auxin response factor gene was highly expressed at middle stem developmental stage in D (T4-57859, Figure 2j). The expression of agmatine coumaroyl transferase gene (T1-64213, Figure $2 \mathrm{k}$ ) and cytokinin dehydrogenase gene (T3-
50471, Figure 21) were unstable. The expression of Ferredoxin-NADP reductase gene was highly at later stage than at early stage in D (T3-5609, Figure 2m). The expression of pyrophosphate-fructose 6-phosphate 1-phosphotransferase subunit beta 1 gene changed little in D (T2-50808, Figure 2n). The expression profiles of this six genes were dissimilar in D and the other three genotypes, and also were different from the above 
eight genes. The fourteen genes were significantly affected by mutation, suggested their important roles during stem development.

\section{DISCUSSION}

\section{Elements specify wheat stem development}

Total 663 genes were identified highly expressed in wheat stem tips, and they were divided into three groups (cellular component, molecular function and biological process) and were assigned to many subcategories base on the GO database. They may play some roles in wheat stem development according to the annotation of GO.

Phytohormone signaling pathways play a key role in wheat stem development: Phytohormones can regulate the plant stem height. For example, GAs is one of the most important endogenous phytohormone effecting on the plant height (CHANDLER et al., 2002; WANG AND LI, 2008). We identified an Abscisic acid (ABA) inducible protein PHV A1 gene and auxin response factor 12 and 25 genes highly expressed in stem tips. This showed that phytohormone signalings were important for stem development.

Homeotic/homeobox genes specify wheat stem: Two homeobox-leucine zipper protein genes in stem tips were obtained. Numbers of genes encoding a member of the HD-Zip families I and II, they express in various plant organs (CHAN et al., 1998), and numbers of HD-Zip families IV genes are expressed in epidermis such as Arabidopsis GLABRA2 (AtGL2) (CHAN et al., 1998; RERIE et al., 1994). This showed the two homeobox-leucine zipper protein genes in this study played some roles in wheat stem development.

Other important genes for wheat stem development: We identified some other genes may play some roles in plant stem development base on GO annotation. WRKY78, one of WRKY transcriptional factor, may effect stem elongation in rice (ZHANG et al., 2011); WRKY13, in Arabidopsis affected the stem development (LI et al., 2015). In Arabidopsis, there are 89 WRKY genes identified now, meanwhile 137 WRKY genes obtained in rice (ZHANG et al., 2011). The WRKY transcription factors may be important for stem development.

\section{Molecular basis of dms stem development}

Phytohormone signaling: Mutation affected BRs, ABA, ethylene, auxin and GAs related genes. BRs and GAs were more important for stem dwarf. Two gibberellin 2-beta-dioxygenase genes (T247104, T3-70314) and one gibberellin receptor GID1 gene (T4-16051) were inhibited in the stems of D, as a result the concentration of gibberellin might be lower, and gibberellin pathway was suppressed. A GA soluble receptor, GID1 regulates stomata development in rice (DU et al., 2015) and mediates GA signaling (GRIFFITHS et al., 2006). GAs are plant tetracyclic diterpenoids that control various processes throughout plant development, including stem elongation (SUN, 2011). Two auxin response factors (T4-57859, T161379) and an ABA inducible protein PHV A1 (T4918) genes were up-regulated in D, but two ethyleneresponsive transcription factors (T2-46568, T1-62457) genes were down-regulated in D. Auxin is the required material for stem elongation (MCSTEEN, 2010), auxin regulates cell growth related metabolism of the cell wall characteristic glucan (INOUHE AND NEVINS, 1991). This suggested that auxin signaling played an important role in stem development. Repressed ethylene signal could inhibit cell division, lead to stem dwarf. These cases suggest that the balance of phytohormone signaling is important for stem development. The signal pathways of auxin and ABA were activated in D, but GAs and ethylene was inhibited, thereby leaded to phytohormone imbalance. The phytohormone signaling was very tanglesome, but the imbalance of phytohormone should be the most important cause in D.

\section{CONCLUSION}

The wheat stem tip transcriptomes of lines $\mathrm{D}$ and $\mathrm{T}$ were compared. We identified 663 genes, which were related to stem development. We identified 997 genes differentially expressed in stem tips between $\mathrm{T}$ and D. Most biological processes of dwarf plants were significantly suppressed, such as signal transduction mechanisms (Table 2). In summary, suppressed GA pathway and phytohormone imbalance may be the major causes for dwarfing of the D plants.

\section{ACKNOWLEDGEMENTS}

This study was supported by the National Natural Science foundation of China (No. 31571646) and The Special Fund for Key Agricultural Project in Henan Province, China in 2016 (No. 161100110400).

\section{REFERENCES}

CHANDLER, P.M; GUBLER, F. Mutants at the Slender1 Locus of Barley cv Himalaya. Molecular and Physiological Characterization. Plant Physiology, v.129, n.1, p.181-190, 2002. Available from: $<\mathrm{http} / / /$ dx.doi.org/10.1104/pp.010917>. Accessed: Apr. 6, 2017. doi:10.1104/pp.010917.

Ciência Rural, v.47, n.12, 2017. 
CHAN, R.L. et al. Homeoboxes in plant development. BBA-Gene Str Exp, v.1442, n.1, p.1-19, 1998. Available from: <http://dx.doi. org/10.1016/S0167-4781(98)00119-5>. Accessed: Seq. 6, 2017. doi: $10.1016 / \mathrm{S} 0167-4781(98) 00119-5$.

DUAN, Z.B. et al. Identification of a novel male sterile wheat mutant dms conferring dwarf status and multi-pistils. Journal of Integrative Agriculture, v.14, n.9, p.1706-1714, 2015. Available from: $\quad<$ http://dx.doi.org/10.1016/S2095-3119(14)60936-9>. Accessed: Apr. 6, 2017. doi: 10.1016/S2095-3119(14)60936-9.

DU, H. et al. GID1 modulates stomatal response and submergence tolerance involving abscisic acid and gibberellic acid signaling in rice. Journal of Integrative Plant Biology, v.57, n.11, p.954-968, 2015. Available from: <http://dx.doi.org/10.1111/jipb.12313> Accessed: Apr. 6, 2017. doi10.1111/jipb.12313.

EISEN, M. B. et al. Cluster analysis and display of genome-wide expression patterns. Proceedings of the National Academy of Sciences of the United States of America, v.95, n.25, p.14863-14868, 1998. Available from: <http://dx.doi.org/10.1073/pnas.95.25.14863>. Accessed: Seq. 5, 2017. doi: 10.1073/pnas.95.25.14863.

GRABHERR, M.G. et al. Full-length transcriptome assembly from RNA-Seq data without a reference genome. Nature Biotechnology, v.29, n.7, p.644-652, 2011. Available from: $<$ http://dx.doi.org/10.1038/nbt.1883>. Accessed: Apr. 6, 2017. doi: $10.1038 /$ nbt. 1883 .

GRIFFITHS, J. et al. Genetic characterization and functional analysis of the GID1 gibberellin receptors in Arabidopsis. Plant Cell, v.18, n.12, p.277-286, 2006. Available from: $<$ http://dx.doi org/10.1105/tpc.106.047415>. Accessed: Apr. 6, 2017. doi: $10.1105 /$ tpc. 106.047415

INOUHE, M.; NEVINS, D.J. Inhibition of auxin-induced cell elongation of maize coleoptiles by antibodies specific for cell wall glucanases. Plant Physiology, v. 96, n.2, p.426-431, 1991. Available from: <http://dx.doi.org/10.1104/pp.96.2.426> Accessed: Apr. 6, 2017. doi: 10.1104/pp.96.2.426.

LI, W. et al. WRKY13 acts in stem development in Arabidopsis thaliana. Plant Sci, v. 236, p.205-213, 2015. Available from: $<$ http://dx.doi.org/10.1016/j.plantsci.2015.04.004>. Accessed: Set. 6, 2017. doi: 10.1016/j.plantsci.2015.04.004.

LIANG, G.H. et al. Fine mapping of a semidwarf gene sd-g in indica rice (Oryza sativa L.). Chinese Science Bulletin, v.49, n.9, p.900-904, 2004. Available from: < http://dx.doi.org/10.1007/ BF03184008>. Accessed: Apr. 6, 2017. doi: 10.1007/BF03184008.

LIVAK, KJ, SCHMITTGEN TD. Analysis of relative gene expression data using real-time quantitative PCR and the $2^{-\triangle \Delta C T}$ method. Methods, v.25, p.402-408, 2001. Available from: $<$ https:// doi.org/10.1006/meth.2001.1262>. Accessed: Jul. 21, 2017. doi: 10.1006/meth.2001.1262.

MCSTEEN, P. Auxin and monocot development. Cold Spring Harbor Perspectives in Biology, v.2, n.3, p.564-571, 2010. Available from: <http://dx.doi.org/10.1101/cshperspect.a001479>. Accessed: Apr. 6, 2017. doi: 10.1101/cshperspect.a001479.

MORTAZAVI, A. et al. Mapping and quantifying mammalian transcriptomes by RNA-Seq. Nature Methods, v.5, n.7, p.621-628, 2008. Available from: <http://dx.doi.org/10.1038/nmeth.1226>. Accessed: Apr. 6, 2017. doi: 10.1038/nmeth.1226.
PENG, J. et al. The Arabidopsis GAI gene defines a signaling pathway that negatively regulates gibberellin responses. Genes \& Development, v.11, n.23, p.3194-3205, 1997. Available from: $<$ http://dx.doi.org/10.1101/gad.11.23.3194>. Accessed: Apr. 6, 2017. doi: 10.1101/gad.11.23.3194.

RERIE, W.G. et al. The GLABRA2 gene encodes a homeo domain protein required for normal trichome development in Arabidopsis. Gene Dev, v. 8, n.12, p.388-399, 1994. Available from: <http://dx.doi.org/10.1101/ gad.8.12.1388>. Accessed: Seq. 6, 2017. doi: 10.1101/gad.8.12.1388.

ROMUALDI C. et al. IDEG6: a web tool for detection of differentially expressed genes in multiple tag sampling experiments. Physiological genomics, v.0, n.12, p.159-162, 2003, Available from: < http://dx.doi.org/ 10.1152/physiolgenomics.00096.2002>. Accessed: Sep. 5, 2017. doi: 10.1152/physiolgenomics.00096.2002.

SUN, T.P. The molecular mechanism and evolution of the GAGID1-DELLA signaling module in plants. Current Biology Cb, v.21, n.9, p.338-345, 2011. Available from: <http://dx.doi. org/10.1016/j.cub.2011.02.036>. Accessed: Apr. 6, 2017. doi: 10.1016/j.cub.2011.02.036.

TAKETO, O. et al. Comparative analysis of transcriptomes in aerial stems and roots of Ephedra sinicabased on high-throughput mRNA sequencing. Genomics Data, v.10, p.4-11, 2016. Available from: <http://dx.doi.org/10.1016/j.gdata.2016.08.003>. Accessed: Apr. 6, 2017. doi: 10.1016/j.gdata.2016.08.003.

WANG, Y. et al. 2015. Comparing the effects of GA-responsive dwarfing genes Rht13, and Rht8, on plant height and some agronomic traits in common wheat. Field Crops Research, v.179, p.35-43, 2015. Available from: <http://dx.doi.org/10.1016/j.fcr.2015.04.010>. Accessed: Apr. 6, 2017. doi: 10.1016/j.fcr.2015.04.010.

WANG, Y.; LI, J. Molecular basis of plant architecture. Annual Review of Plant Biology, v.59, n.59, p.253-279, 2008. Available from: <http:// dx.doi.org/10.1146/annurev.arplant.59.032607.092902>. Accessed: Apr. 6, 2017. doi: 10.1146/annurev.arplant.59.032607.092902.

WU, J. et al. Dominant and pleiotropic effects of a GAI gene in wheat results from a lack of interaction between DELLA and GID1. Plant Physiology, v.157, n.4, p.2120-2130, 2011. Available from: <http://dx.doi.org/10.1104/pp.111.185272>. Accessed: Apr. 6, 2017. doi: 10.1104/pp.111.185272.

YAMAGUCHI, S. Gibberellin metabolism and its regulation. Plant Biology, v.59, n.59, p.225-251, 2008. Available from: $<$ http://dx.doi. org/10.1146/annurev.arplant.59.032607.092804>. Accessed: Apr. 6, 2017. doi: 10.1146/annurev.arplant.59.032607.092804.

ZHANG, C.Q. et al. The WRKY transcription factor OsWRKY78 regulates stem elongation and seed development in rice. Planta, v. 234, p.541-554, 2011. Available from: < http://dx.doi.org/10.1007/ s00425-011-1423-y>. Accessed: Seq. 6, 2017. doi: 10.1007/ s00425-011-1423-y.

ZHANG, H. et al. PlantTFDB 2.0: update and improvement of the comprehensive plant transcription factor database. Nucleic Acids Res, v. 39, n.1, p.1114-1117, 2011. Available from: <http://dx.doi.org/10.1093/ nar/gkq1141>. Accessed: Seq. 6, 2017. doi: 10.1093/nar/gkq1141.

ZHU, X.X. et al. Transcriptome Analysis for Abnormal Spike Development of the Wheat Mutant dms. Plos One, v.11, n.3, p. e0149287, 2016. Available from: $<\mathrm{http}: / / \mathrm{dx}$.doi.org/10.1371/journal.pone.0149287>. Accessed: Apr. 6, 2017. doi: 10.1371/journal.pone.0149287. 